\title{
RBM38 wt Allele
}

National Cancer Institute

\section{Source}

National Cancer Institute. RBM38 wt Allele. NCI Thesaurus. Code C99642.

Human RBM38 wild-type allele is located in the vicinity of 20q13.31 and is approximately $18 \mathrm{~kb}$ in length. This allele, which encodes RNA-binding protein 38, plays a role in the regulation of mRNA stability. 